\title{
Response of Information Technology Companies in Europe to the World Health Organization's Announcement of the COVID-19 Pandemic
}

Katerina Lyroudi

Hellenic Open University, Greece

Fatbardha Morina

Epoka University, Albania

Chrysanthi Balomenou

Epoka University, Albania

\section{Abstract}

From the beginning of 2020, the whole world has been shaken by a contagious disease called Covid-19, its actual name being SARS-CoV-2. It first appeared in China, in Wuhan, Hubei Province, in December 2019, and the World Health Organization (WHO) was informed about it on the 31st of December 2019. On the $11^{\text {th }}$ of March, 2020, WHO declared the Covid-19 outbreak a pandemic, and no country has been able to contain this coronavirus. This medical or health crisis evolved into a pandemic and led to a global economic crisis. This study investigates the wealth effect of the coronavirus pandemic announcement on the Information Technology Industry companies in Europe. We apply the classical event study methodology. Our sample contained 87 companies. The results show a strong negative reaction of information technology companies upon this announcement. The European investors perceived this announcement as a negative signal that will disturb the lives of everyone and will create economic instabilities and havoc in all sectors of an economy.

Keywords: market reaction, event study, Covid-19 crisis JEL classification: G14, G30

Paper type: Research article Received: Mar 10, 2021 Accepted: May 5, 2021

DOI: $10.54820 /$ XOWK9116 


\section{Introduction}

From the beginning of 2020, the whole world was shaken from a disease called Covid-19, whereby the actual name is SARS-CoV-2, and it is very contagious. It appeared first in China, in Wuhan, Hubei Province, in December 2019 (Yang et al., 2020), and the World Health Organization (WHO) was informed on the 31st of December 2019. On the 11th of March, 2020, the WHO declared the Covid-19 a pandemic, and after a year, no country has been able to contain this coronavirus yet. This medical or health crisis evolved into a pandemic and led to an economic crisis globally. On the 27th of February, 2020, the NASDAQ-100, the S\&P 500 Index, and the Dow Jones Industrial Average indices in the USA dropped more than they did in the Global Financial Crisis (GFC) in 2008. From the 9th of March 2020 to the 12th of March 2020, the FTSE index in the UK dropped more than $10 \%$. Most governments announced and imposed severe measures that resulted in all retail and wholesale companies, restaurants, cafes, bars, hotels, kindergartens, schools, and universities being closed. Only the food suppliers and pharmacies remained operational, and only the people in those sectors and the civil servants were working and earning their living. Therefore, the companies in all industries were affected, but the effect was not the same and to the same degree among the industries and the different countries.

This study investigates the wealth effect of the coronavirus pandemic announcement on the Information Technology Industry companies in Europe. We apply the classical event study methodology for our purpose. Our results will be valuable for academicians enriching the pertinent literature, for investors that have to make decisions under a health crisis uncertainty in selecting their portfolio of stocks or restructure their portfolios accordingly, and for policymakers to guide them in making the proper decisions regarding the fight for the virus contamination restriction from one point and the protection of the economy from the other.

The rest of the paper is organized as follows: the next section presents the relevant review of the literature. The third section contains the data, the methodology, and the testable hypotheses. The fourth section depicts and analyses our empirical results, and the final section summarizes the paper and offers future research ideas.

\section{Literature review}

There are quite a few studies that analyze the impact of the Covid-19 on different markets and economies from different aspects. We focus on the most relevant studies.

Few studies examine the impact of the shock of pandemic diseases on stock market returns, and investors who consider investing that due to the shock has changed. Goh et al. (2002) found that the 1997 Asian financial crisis and the 1998 Hong Kong avian influenza outbreak had a significant negative impact on tourism. Chen et al. (2007) studied the impact of SARS on the hotel industry for Taiwan and found that SARS caused the stock prices of the hotel industry to drop. Mctier et al. (2011) studied the impact of flu on stock market returns for the US and found that it was negative since an increase in the flu rate would reduce trading activities and thus stock returns.

Gurav et al. (2020) found that the coronavirus pandemic spread fear and uncertainty, and investors having these negative sentiments were influenced their investments decisions. Consequently, there were negative effects on the stock market prices. Goodell (2020) investigated the tremendous economic and social effects of COVID-19 on various financial markets and industries from the existing 
literature and outlined the effects of other previous health crises that affected the markets to derive possible future ways of overcoming the problem.

Azimli (2020) examined the effect of the Covid-19 health crisis on the risk and return relationship for ten selected industry sectors of the US market, according to the GICS code classification, during the period the 1st of January 2020 to the 31 st of March, 2020. The information technology industry was included in his sample. His results showed that the market reaction to this health crisis was similar to the 2008 global financial crisis.

Alam et al. (2020), for the market of India, investigated the market reaction in the pre-lockdown and post- lockdown period caused by the Covid-19 pandemic. They used event study methodology whereby the event day was the lockdown announcement date on the 24th of March, 2020. The first case of the disease occurred on the 30th of January. Therefore, there was an negative market reaction (negative AARs) during the pre-lockdown period from the first case till the announcement of the lockdown and a positive market reaction (positive AARs) during the after-lockdown period. The results in the first sub-period expressed the uncertainty and fear of the investors. In contrast, the results in the second sub-period expressed the investors' relief since the government took some measures to contain the pandemic.

Huo et al. (2020) examined how China's stock market reacted to the coronavirus pandemic in 2020, specifically the pandemic lockdown announcement. The retail industry had a substantial negative reaction to the COVID-19 outbreak, while the pharmaceutical, biotechnology, computer, and electronics industries had a positive reaction. Another related study for China is Pinglin et al. (2020), who studied Chinese industries' market reaction and response trends to the coronavirus pandemic. They applied event study methodology, and their results indicated that the COVID-19 pandemic had a severe negative impact on industries, such as transportation, mining, electricity and heating, and the environment. In contrast, it had a positive effect on manufacturing information technology, education, and health industries.

Apergis et al. (2020) examined the effect of the health crisis due to the Covid-19 pandemic on the stock market returns and risk for the market of China. They found that the daily announcements of total confirmed Covid-19 cases and deaths in China significantly negatively affected shares. A stock returns and a significant positive effect on the volatility of these market returns.

Therefore, based on the literature, it is exciting and intriguing to see what will be the impact of the COVID-19 pandemic announcement on the stock returns of companies in the information technology industry in Europe, which to our knowledge has not been done yet, and this is our contribution to the pertinent literature.

\section{Methodology}

Our sample is consisted of all the information technology companies listed in the European stock markets and is part of the EuroSTOXX600 index, total number 87. The variables used are daily stock prices of the selected companies and the EuroSTOXX index as a proxy for the market portfolio in the market model. All the data were collected from the Thomson EIKON database from the 1st of January 2018 to the 14th of April 2020.

The reason for selecting this sector is that the information technology industry is the fastest growing industry in the 21 st century. Most individuals and organizations use its products and services, so it would be fascinating to examine the market reaction of these companies to the covid-19 pandemic announcement. This industry sector, the Information Technology industry, has code number 45 in the Global Industry 
Classification Standard (GICS). Specifically, three IT industry groups have the relative codes, such as 4510 Software and Information Technology Services, 4520 Technology Hardware and Equipment, and 4530 Semiconductors and Semiconductor Equipment.

We hypothesize that there is expected to be a positive market reaction of the information technology European companies to announce that Covid-19 is a pandemic by the WHO. Based on the pandemic announcement by the WHO, the governments reacted by imposing severe lockdowns on their citizens, and almost everybody turned to computer technology for communicating, being informed, for working (teleworking), for teaching in schools and universities, and any other educational institution, for entertainment and shopping. Almost all aspects of human life are connected with computers and all the technology and applications. Therefore, this industry was not hurt by the pandemic announcement; but instead, it was expected to flourish. The other related study of Huo et al. (2020) that examined China's technology industry showed that the impact of covid-19 was positive, so we formed our hypothesis based on these facts.

We apply the event study methodology according to Brown et al. (1985). The market model assumes a linear relationship between the returns of the market portfolio and the returns of the securities. We try to measure how rapidly security prices respond to announcements, specifically to the pandemic announcement by WHO due to the Covid-19, on the 11 th of March, 2020, by using the market model for stock returns as specified by Madura et al. (1989).

The daily stock returns are calculated using daily stock prices data from the Refinitiv EIKON database for each company in the sample. The estimation period ranges from day $t=-531$ to $t=-21$, relative to the WHO announcement day of a Covid19 pandemic on the 11 th of March, 2020 (day $t=0$ ). In the case of stock splits, the computation of daily returns was adjusted accordingly. For the period from the 1st of January 2018 to the 14th of April,2020 the EuroSTOXX600 equity index is used as the market portfolio proxy.

Specifically, the impact of the pandemic announcement on the stock price of the sponsoring companies is estimated using the following market model for stock returns:

$$
R_{j t}=a_{j}+b_{j} R_{m t}+e_{j t}
$$

where: $\quad R_{j \dagger}=$ daily return of the jth company on day $t$.

$R_{m t}=$ daily return of the market on day $t$.

$a_{j}=$ intercept of the market model.

$b_{j}=\operatorname{COV}\left(R_{j t}, R_{m}\right) / \operatorname{VAR}\left(R_{m t}\right)$, slope of the market model, which measures the systematic risk of the jth company.

$e_{j t}=$ error term, assumed to be normally distributed, with zero mean $\left[E\left(e_{j t}\right)=0\right.$ ] and constant variance $\left[\operatorname{COV}\left(e_{j t-1}, e_{j t}\right)=0\right]$.

After the market model is estimated by the Ordinary Least Squares (OLS), we use the calculated parameters over the estimation period to derive the expected returns for each security over an estimation period of 40 days, from day $t=-20$ to $t=+20$, around the event date (day $t=0)$ :

$$
E\left(R_{j t}\right)=a_{j}+\beta_{j} R_{m t}
$$


The intercept estimate $\left(a_{j}\right)$ should be equal to zero for the market model to be well specified for each stock in the portfolio. The estimate of the slope $\left(\beta_{j}\right)$ would indicate the systematic risk of security j. If it were zero, it would indicate that market factors do not influence the returns of that particular stock. If it were larger, less, or equal to one, it would imply that the particular company was more, less, or equally risky, respectively, to the market portfolio.

The difference between the actual return $R_{j t}$ and the expected return $E\left(R_{j t}\right)$ for each stock from day -20 to +20 gives the abnormal returns $A R_{j t}$ for each firm in the sample for each day of the examination period. These are defined as:

$$
\begin{gathered}
A R_{j t}=R_{j t}-E\left(R_{j t} \quad t=-20, \ldots \ldots . .,+20(3)\right. \\
\text { or } \\
A R_{j t}=R_{j t}-\left(a_{j}+\beta_{j} R_{m t}\right)
\end{gathered}
$$

The portfolio average abnormal return for each day is:

$$
\mathrm{AR}_{\mathrm{p \dagger}}=\frac{\left(\sum_{j=1}^{N} A R_{j t}\right)}{N} \quad \mathrm{t}=-20, \ldots \ldots .,+20, \mathrm{~N}=87
$$

The abnormal returns are derived from Equations 1 and 2, as it is expressed in Equation 3. In simple words, if there is no severe market reaction around the event day, the returns estimated based on the market model should be the same as those observed on those days. Therefore, their difference that makes the abnormal return for that particular day will be close to zero or insignificant. If, on the other hand, there is a substantial market reaction, then the calculated or estimated returns will be different from the actual ones on each selected day. These differences whereby from the actual returns on a specific day we subtract the estimated returns from the market model are the abnormal returns and can be tested for significance. If those differences, the abnormal returns (ARs), are positive, we discuss a positive market reaction. In other words, the investors have reacted in reality with higher returns than the estimated ones, which indicates a good perception of the specific event we examine by the investors or the market. If, on the other hand, the abnormal returns (ARs) are negative, then we are discussing an negative market reaction. In other words, the investors have reacted in reality with lower returns than the estimated ones, which indicates a wrong perception of the specific event we examine by the investors or the market.

This portfolio average abnormal return for each day is tested for significance with the following t-statistic:

$$
\mathrm{\dagger}=\frac{A R_{p t}}{\operatorname{STD}\left(A R_{p t}\right)}
$$


Where STD $\left(A R_{p t}\right)$ is the standard deviation of $A R_{p t}$ for the period from day $t=-531$ to $t=-21$.

The cumulative average abnormal returns (CARs) are computed and used to capture the overall impact of the COVID-19 pandemic announcement effect on shareholders' wealth. They are obtained by summing the average portfolio ARs over the examination period.

$$
\mathrm{CAR}_{\mathrm{pT} 1, \mathrm{~T} 2}=\sum_{t=T 1}^{T 2} A R_{p t}
$$

Where $\mathrm{T} 1$ is the beginning of the event period, and $\mathrm{T} 2$ is the end. The null hypothesis is that the CARs are equal to zero. The following is the formula for tstatistic:

$$
\dagger=\frac{C A R_{p}}{S T D\left(C A R_{p}\right)}
$$

where $\operatorname{STD}\left(C A R_{p}\right)$ represents the standard deviation of $C A R_{p}$ and is estimated as follows:

$$
\operatorname{STD}\left(\mathrm{CAR}_{\mathrm{p}}\right)=\sqrt{\operatorname{VAR}\left(A R_{p t}\right)^{*} T}
$$

Where $T$ represents the number of trading days in the interval examined, the variance is estimated for the period from day $t=-531$ to $t=-21$ (estimation period) since we assume that the variability of the returns should be the same for the period before and after the event.

\section{Results}

Table 1 depicts the Information Technology portfolio abnormal returns for the examination period 20 days before and 20 days after the event day, the 11 th of March, 2020, WHO announced that Covid-19 was a pandemic. Based on the results presented in Table 1, we observe that this announcement negatively affected the Information Technology industry in Europe since the value of the ARo is equal to 0.01789 ( $t=-2.571)$, significant at the $5 \%$ level of a two-tailed test. We observe that the market reaction is negative on days $1,3,4$, and 5 . On day two, the market reaction was positive and significant. We focus on the cumulative average abnormal returns. We see that the market reaction is negative and significant for the period from day 1 to day 13 after the announcement and then continues to be negative till day 20 , but not statistically significant.

Therefore, our results are in contrast to our hypothesis, and they are also in contrast to the results for the Chinese information technology industry of Huo et al. (2020) and Pinglin et al. (2020). 
Table 1

Abnormal Returns of the Examination Period

\begin{tabular}{|c|c|c|c|c|}
\hline Day & $\begin{array}{l}\text { Average Abnormal } \\
\text { Returns ARs }\end{array}$ & t-Statistic & $\begin{array}{l}\text { Cumulative Average } \\
\text { Abnormal Returns CARs }\end{array}$ & t-Statistic \\
\hline 20 & $0.014200 *$ & 2.040790 & -0.01023 & -0.32871 \\
\hline 19 & 0.007994 & 1.148948 & -0.02443 & -0.80544 \\
\hline 18 & 0.006579 & 0.945573 & -0.03242 & -1.09832 \\
\hline 17 & -0.000390 & -0.055370 & -0.03900 & -1.35950 \\
\hline 16 & -0.006900 & -0.991760 & -0.03862 & -1.38749 \\
\hline 15 & 0.008396 & 1.206697 & -0.03172 & -1.17693 \\
\hline 14 & 0.009433 & 1.355667 & -0.04011 & -1.54074 \\
\hline 13 & $0.012783^{* *}$ & 1.837092 & $-0.04955^{* *}$ & -1.97489 \\
\hline 12 & 0.008135 & 1.169144 & $-0.06233^{*}$ & -2.58586 \\
\hline 11 & -0.004560 & -0.656070 & $-0.07046^{*}$ & -3.05335 \\
\hline 10 & 0.005804 & 0.834097 & $-0.06590^{*}$ & -2.99491 \\
\hline 9 & -0.006890 & -0.990610 & $-0.07170 *$ & -3.43495 \\
\hline 8 & -0.005100 & -0.732540 & $-0.06481^{*}$ & -3.29308 \\
\hline 7 & 0.004795 & 0.689122 & $-0.05971^{*}$ & -3.24357 \\
\hline 6 & 0.000763 & 0.109718 & $-0.06451^{*}$ & -3.78479 \\
\hline 5 & -0.000480 & -0.068640 & $-0.06527^{*}$ & -4.19510 \\
\hline 4 & $-0.029090^{*}$ & -4.180590 & $-0.06479 *$ & -4.65594 \\
\hline 3 & $-0.017670 *$ & -2.540040 & $-0.03570 *$ & -2.96255 \\
\hline 2 & $0.012492^{* *}$ & 1.795295 & $-0.01803^{* *}$ & -1.83229 \\
\hline 1 & $-0.012630^{* *}$ & -1.815780 & $-0.03052 *$ & -4.38655 \\
\hline Day 0 & $-0.017890^{*}$ & -2.570770 & $-0.01789 *$ & -2.57077 \\
\hline-1 & -0.002000 & -0.286920 & & \\
\hline-2 & 0.007986 & 1.147691 & & \\
\hline-3 & 0.007187 & 1.032932 & & \\
\hline-4 & 0.001757 & 0.252520 & & \\
\hline-5 & $-0.020820 *$ & -2.991730 & & \\
\hline-6 & 0.003433 & 0.493392 & & \\
\hline-7 & 0.006552 & 0.941589 & & \\
\hline-8 & 0.003144 & 0.451777 & & \\
\hline-9 & -0.002840 & -0.407590 & & \\
\hline-10 & -0.000660 & -0.094950 & & \\
\hline-11 & 0.001342 & 0.192885 & & \\
\hline-12 & -0.010500 & -1.508560 & & \\
\hline-13 & -0.000300 & -0.042490 & & \\
\hline-14 & 0.007064 & 1.015156 & & \\
\hline-15 & -0.005580 & -0.802640 & & \\
\hline-16 & -0.007690 & -1.105890 & & \\
\hline-17 & -0.002710 & -0.390120 & & \\
\hline-18 & -0.005190 & -0.745530 & & \\
\hline-19 & -0.003770 & -0.542230 & & \\
\hline-20 & 0.002102 & 0.302055 & & \\
\hline
\end{tabular}

* Indicates significance at the 5\% level of a two-tailed test.

** Indicates significance at the $10 \%$ level of a two-tailed test.

Source: Own calculations

Probably in Europe, investors panicked more by such a health crisis and reacted based on the sentiments of fear and uncertainty. They did not consider the status of this industry under the new conditions that it will be the most crucial industry in the cases of lockdowns, and its operations will not stop or be reduced. The Chinese investors seem to be more mature. Their reaction showed that they recognize the potential for growth of this industrial sector even under the crucial 
conditions of severe lockdowns and economic uncertainty. According to our review of literature on page 3, we mention the study of Huo et al. (2020), who examined how China's stock market reacted to the pandemic lockdown announcement because of the coronavirus pandemic in 2020. They found that the retail industry had a strong negative reaction to the COVID-19 outbreak, with negative cumulative abnormal returns.

In contrast, the computer and electronics industries had a continuous positive reaction even after a month. Therefore, Pinglin et al. (2020) investigated Chinese industries' market reaction and response trends to the coronavirus pandemic. They applied event study methodology, and their results indicated that the COVID-19 pandemic had a severe negative impact on industries, such as transportation, mining, electricity and heating, and the environment. In contrast, it had a positive effect on manufacturing information technology, education, and health industries. Based on these results, it is clear that the Chinese investors had positive cumulative abnormal returns in the information technology and computer industries, implying that they estimated those industries' risk and future performance correctly. It seems that they realized the potential of the information technology and computer industries to grow even under the conditions of severe lockdowns, hence their positive reaction.

\section{Conclusion}

This study investigated the market reaction of the information technology industry in Europe to WHO's announcement that Covid-19 is a pandemic on the 11 th of March, 2020. Contrary to our hypothesis, we found a strong negative reaction to this announcement. A possible explanation is that European investors were terrified by this health crisis and did not react logically but by letting their opinions govern their decisions. The European investors perceived this announcement as a negative signal that will disturb the lives of everyone and will create economic instabilities and havoc in every sector of an economy.

Future research could be directed towards examining this reaction for various industries in Europe and the USA markets and determining the factors that may cause any differences. These results will be important for the policymakers to help them make better decisions regarding the stock markets' operations and investors' protection.

\section{References}

1. Alam, M. N., Alam, M. S., Chavali, K. (2020), "Stock Market Response during COVID-19 Lockdown Period in India: An Event Study", Journal of Asian Finance, Economics and Business, Vol. 7 No. 7, pp. 131-137.

2. Apergis, N., Apergis, E. (2020), "The role of Covid-19 for Chinese stock returns: evidence from a GARCHX model", Asia-Pacific Journal of Accounting \& Economics, DOI: 10.1080/16081625.2020.1816185 (08 May 2021)

3. Azimli, A. (2020), "The impact of COVID-19 on the degree of dependence and structure of risk-return relationship: A quantile regression approach", Finance Research Letters, Vol. 36, pp. 1-5.

4. Brown, S. J., Warner, J. B. (1985), "Using Daily Stock Returns, The Case of Event Studies", Journal of Financial Economics, Vol. 14 No. 1, pp. 3-31.

5. Chen, M. H., Jang, S. C., Kim, W. G. (2007), "The impact of the SARS outbreak on Taiwanese hotel stock performance: An event-study approach", International Journal of Hospitality Management, Vol. 26 No. 1, pp. 200-212. 
6. Goh, C., Law, R. (2002), "Modeling and forecasting tourism demand for arrivals with stochastic nonstationary seasonality and intervention", Tourism Management, Vol. 23 No. 5, pp. 499-510.

7. Goodell, J. W. (2020), "COVID-19 and finance: Agendas for future research", Finance Research Letters, Vol. 35, pp. 1-13.

8. Gurav, U., Kotrappa, D. S. (2020), "Impact of COVID-19 on stock market performance using efficient and predictive LBL-LSTM based mathematical model", International Journal on Emerging Technologies, Vol. 11 No. 4, pp. 108-115.

9. Huo, X., Qiu, Z. (2020), "How does China's stock market react to the announcement of the COVID-19 pandemic lockdown?", Economic and Political Studies, Vol. 8 No. 4, pp. 436-461.

10. Madura, J., McDaniel, W. R. (1989), "Market Reaction to Increased Loan Loss Reserves at Money-Center Banks", Journal of Financial Services Research, Vol. 3, pp. 359-369.

11. Mctier, B. C., Tse, Y., Wald, J. K. (2011), "Do stock markets catch the flu?", Journal of Financial \& Quantitative Analysis, Vol. 48 No. 3, pp. 979-1000.

12. Pinglin, H., Yulong, S., Ying, Z., Tao, L. (2020), "COVID -19's Impact on Stock Prices Across Different Sectors - An Event Study Based on the Chinese Stock Market", Emerging Markets Finance and Trade, Vol. 56 No. 10, pp. 2198-2212.

13. Yang, Y., Peng, F., Wang, R., Guan, K., Jiang, T., Xu, G., Sun, J., Chang, C. (2020), "The deadly coronaviruses: The 2003 SARS pandemic and the 2020 novel coronavirus epidemic in China", Journal of autoimmunity, Vol. 109, pp. 1-16.

\section{About the authors}

Katerina Lyroudi, Ph.D., works at the Hellenic Open University, Greece. The author can be contacted at lyrkat@gmail.com

Fatbardha Morina works as the Assistant Lecturer at Epoka University. She graduated from the Aleksander Moisiu University of Durrës, where she finished the Master of Science in Banking and Finance, and now she is doing her Ph.D. at Epoka University. Her research interests are innovation, renewable energy. The author can be contacted at email fmorina@epoka.edu.com

Chrysanthi Balomenou, Ph.D., works at the Epoka University, Albania. The author can be contacted at cbalomenou@epoka.edu.al

\section{Appendix. List of examined companies}

\begin{tabular}{lll}
\hline $\begin{array}{l}\text { European Company } \\
\text { Common Name }\end{array}$ & Stock exchange country & GICS Industry Group Code \\
\hline Worldline SA & France & 4510 \\
Sinch AB (publ) & Sweden & 4510 \\
Siltronic AG & Germany & 4530 \\
Bechtle AG & Germany & 4510 \\
ams AG & Switzerland & 4530 \\
Adyen NV & Netherlands & 4510 \\
Capgemini SE & France & 4510 \\
Logitech International SA & Switzerland & 4520 \\
Halma PLC & United Kingdom & 4520 \\
BE Semiconductor Industries & Netherlands & 4530 \\
NV & & \\
TeamViewer AG & Germany & 4510 \\
Amadeus IT Group SA & Spain & 4510 \\
Nexi SpA & Italy & 4510 \\
\hline
\end{tabular}




\begin{tabular}{|c|c|c|}
\hline Sopra Steria Group SA & France & 4510 \\
\hline $\begin{array}{l}\text { Telefonaktiebolaget LM } \\
\text { Ericsson }\end{array}$ & Sweden & 4520 \\
\hline Infineon Technologies AG & Germany & 4530 \\
\hline Edenred SA & France & 4510 \\
\hline Temenos AG & Switzerland & 4510 \\
\hline Atos SE & France & 4510 \\
\hline Sage Group PLC & United Kingdom & 4510 \\
\hline AVEVA Group PLC & United Kingdom & 4510 \\
\hline Dassault Systemes SE & France & 4510 \\
\hline Netcompany Group A/S & Denmark & 4510 \\
\hline ASM International NV & Netherlands & 4530 \\
\hline Spectris PLC & United Kingdom & 4520 \\
\hline ASML Holding NV & Netherlands & 4530 \\
\hline Dialog Semiconductor PLC & Germany & 4530 \\
\hline Nemetschek SE & Germany & 4510 \\
\hline Alten SA & France & 4510 \\
\hline STMicroelectronics NV & Italy & 4530 \\
\hline Avast PLC & United Kingdom & 4510 \\
\hline Nokia Oyj & Finland & 4520 \\
\hline SAP SE & Germany & 4510 \\
\hline Softwareone Holding AG & Switzerland & 4520 \\
\hline Soitec SA & France & 4530 \\
\hline Simcorp A/S & Denmark & 4510 \\
\hline Hexagon $A B$ & Sweden & 4520 \\
\hline Anoto Group AB & Sweden & 4520 \\
\hline Avensia $A B$ & Sweden & 4510 \\
\hline Beijer Electronics Group AB & Sweden & 4520 \\
\hline Concejo AB (publ) & Sweden & 4520 \\
\hline Doro AB & Sweden & 4520 \\
\hline Fingerprint Cards $A B$ & Sweden & 4520 \\
\hline Free2Move Holding $A B$ & Sweden & 4520 \\
\hline Image Systems AB & Sweden & 4520 \\
\hline Firefly $A B$ & Sweden & 4520 \\
\hline Fortnox $A B$ & Sweden & 4510 \\
\hline MultiQ International AB & Sweden & 4520 \\
\hline Enea AB & Sweden & 4510 \\
\hline FormPipe Software AB & Sweden & 4510 \\
\hline HMS Networks AB & Sweden & 4520 \\
\hline Novotek AB & Sweden & 4510 \\
\hline Addnode Group AB (publ) & Sweden & 4510 \\
\hline $\begin{array}{l}\text { JLT Mobile Computers AB } \\
\text { (publ) }\end{array}$ & Sweden & 4520 \\
\hline Hexagon AB & Sweden & 4520 \\
\hline Mycronic AB (publ) & Sweden & 4520 \\
\hline Miris Holding AB (publ) & Sweden & 4520 \\
\hline Generic Sweden AB (publ) & Sweden & 4510 \\
\hline Confidence International AB & Sweden & 4520 \\
\hline LC Tec Holding AB & Sweden & 4520 \\
\hline Diadrom Holding AB & Sweden & 4510 \\
\hline Net Insight $A B$ & Sweden & 4520 \\
\hline Empir Group AB & Sweden & 4510 \\
\hline Knowit $A B$ (publ) & Sweden & 4510 \\
\hline Precio Fishbone $A B$ & Sweden & 4510 \\
\hline Obducat $A B$ & Sweden & 4530 \\
\hline Note $A B$ (publ) & Sweden & 4520 \\
\hline
\end{tabular}




\begin{tabular}{|c|c|c|}
\hline Proact IT Group AB & Sweden & 4510 \\
\hline Precise Biometrics AB & Sweden & 4520 \\
\hline Exalt $A B$ (publ) & Sweden & 4510 \\
\hline Micro Systemation AB (publ) & Sweden & 4510 \\
\hline Paynova AB & Sweden & 4510 \\
\hline Prevas AB & Sweden & 4510 \\
\hline Westpay AB & Sweden & 4520 \\
\hline Softronic AB & Sweden & 4510 \\
\hline Allgon AB (publ) & Sweden & 4520 \\
\hline Vindico Group AB (publ) & Sweden & 4520 \\
\hline Pricer $A B$ & Sweden & 4520 \\
\hline Sensys Gatso Group AB & Sweden & 4520 \\
\hline $\begin{array}{l}\text { Vitec Software Group } A B \\
\text { (publ) }\end{array}$ & Sweden & 4510 \\
\hline TagMaster AB & Sweden & 4520 \\
\hline Binero Group AB (publ) & Sweden & 4510 \\
\hline $\begin{array}{l}\text { Telefonaktiebolaget LM } \\
\text { Ericsson }\end{array}$ & Sweden & 4520 \\
\hline Lagercrantz Group AB & Sweden & 4520 \\
\hline Ework Group AB & Sweden & 4510 \\
\hline IAR Systems Group AB & Sweden & 4510 \\
\hline Jojka Communications $A B$ & Sweden & 4510 \\
\hline
\end{tabular}

Source: Thomson Reuters Eikon 